Dobrivoje Vulicevic, poru cnik, dipl. inž. Vojna akademija - Odsek logistike, mr Dušan Bobic pukovnik, dipl. inž. Uprava za školstvo - Sektor za ljudske resurse MO Beograd

\section{SOFTVERSKO REŠENJE ZA PLANIRANJE NASTAVNOG PROCESA U VISOKOŠKOLSKIM USTANOVAMA}

Rezime:

Planiranje nastavnog procesa $u$ visokoskolskim ustanovama je veoma složen proces. $U$ osnovi, planiranje nastavnog procesa za jednu školsku godinu obuhvata izradu rasporeda casova i planiranje ispitnih rokova. $U$ radu je predstavljen informacioni sistem za automatizaciju planiranja rasporeda casova i ispitnih rokova koji obuhvata dva softverska rešenja. Softverska rešenja omog ucavaju unos i cuvanje svih relevantnih podataka o predme tima, ispitima, nastavnicima, nastavnim grupama, specijalnostima, terminima ispita (datumima), brojnom stanju grupa, prostorijama (ucionice, laboratorije) i brzu izradu potrebnih izveštaja prema korisnicima.Softverska rešenja obuhvataju bazu podataka projektovanu na platformi ,,Microsoft SQL Server 2000“ i korisnicki interfejs projektovan alatom „Microsoft Access 2000“.

Ključne reči: raspored casova, plan ispita, informacioni sistem, softver.

\title{
SOFTWARE SOLUTION FOR PLANNING TIME TABLES AND EXAM TERMS IN THE HIGH EDUCATIONAL INSTITUTIONS
}

\section{Summary:}

Planning time tables and exam terms in the high educational institutions is very complex and tiresome process. This paper presents information system for automatization of planning time tables and exam terms. Software provides input and saving of all relevant data concerning subjects, teachers, exams, terms (dates), specialities, student groups and quick presentation of different report types about time tables and exam terms. The software solution envolves data base designed on „Microsoft SQL Server 2000“ platform and user interface coded using „Microsoft Access 2000“.

Key words: time table, exam term, information system, software.

\section{Uvod}

Jedan od bitnih zadataka koje realizuje nastavno odeljenje visokoškolske ustanove jeste pla niranje i izrada rasporeda casova i izrada pla na is pita. Struktura vojne visokoškolske ustanove, kao što je Vojna akademija, veoma je složena i predstavlja skup fakulteta razlicitih usmerenja. Školovanje traje cetiri ili pet godina, a da bi student us pešno za vršio školovanje treba da položi prosecno 52 ispita. Semestralno za jednu nastavnu grupu pla nira se od sedam do de vet predmeta. Pojedine predmete sluša više nastavnih grupa istovremeno. Prema Nastavnom planu i programu ukupan broj predmeta za pojedine specijalnosti premašuje 500 (za ukupno vreme školovanja). U jednom semestru pla niranje nastavnog procesa, kroz izradu rasporeda casova i pla niranje is pitnih rokova, obuhvata u proseku više od 100 razlicitih predmeta. Planom je potrebno predvideti 
termine realizacije predmeta, termine polaganja ispita (pismeni i usmeni deo), nastavnu grupu (smer, godinu školovanja, kla su i specijalnost), predmet, nastavni$\mathrm{ka}$, prostoriju za realizaciju nastave $\mathrm{i}$ ispita i brojno stanje slušalaca, odnosno broj prija vlje nih kandidata za is pit.

Dosadašnje rešenje pla niranja nastavnog procesa zasnivalo se na izradi rasporeda casova i pla na is pita, popunja vanjem obrazaca izradenih $u$ ala tu Mic rosoft Word. Ovakav pristup imao je niz nedostataka zbog izuzetno teškog generisanja odgovarajucih izveštaja, velikog angažovanja planskog organa, ne mogucnosti automatske validacije unetih podataka $\mathrm{i}$ velike mogucnosti na stanka greške.

U radu je predstavlje no softversko rešenje za planiranje i izradu rasporeda casova $\mathrm{i}$ is pitnih rokova. Softver omogucuje, nakon unosa relevantnih podataka, lako i brzo kreiranje izveštaja prema korisnicima, pracenje realizacije nastave $\mathrm{i}$ ispita, ažuriranje podataka, automatsku proveru podataka otkrivanjem eventualnih grešaka nastalih u pla niranju i jednostavno kreiranje podloge za izradu rasporeda i pla na is pita $u$ narednom semestru ili školskoj godini.

\section{Analiza proble ma}

Izrada rasporeda casova i plana is pita popunja vanjem obrazaca izradenih $u$ ala tu Microsoft Word zahteva ne prekidan unos svakog poje dinacnog podatka $\mathrm{i}$ stalnu proveru podataka iz nastavne dokumentacije i evidencije studentske službe. Znacajnu poteškocu predstavljaju i naknadne izmene rasporeda casova i plana is pita, što je posle dica dodatnih zahteva ucesnika u realizaciji nastave $\mathrm{i}$ ispita.
Dosadašnji nacin rada zahtevao je prekrajanje i ponovno uskladivanje termina (vodeci racuna da ne dode do preklapanja, odnosno istovremenog planiranja $\mathrm{dva}$ predmeta $\mathrm{u}$ istoj prostoriji ili istovremeno pla niranje jednog nastavnika u razlicitim grupama, kao i pla niranja dva ispita istog da tuma, itd.), uz višednevni rad referenata $u$ nastavnom odeljenju. Poš to se svi navedeni proble mi nisu mogli uspešno rešiti modifikovanjem postojeceg rešenja, odluceno je da se pristupi projektovanju informacionog sistema koji ce omoguciti izradu rasporeda casova i plana is pita, tako što ce se kroz izradu baze poda taka automatizova ti sle deci procesi:

- unošenje podataka o predmetima (predavanja, vežbe, fond) po sme rovima i specijalnostima (NPP) i unošenje podataka o nastavnicima (or ganizaciona je dinica, predmet), uz maksimalno smanjenje mogucnosti nastanka greške, kao posle dice ljudskog faktora;

- unošenje podataka o smerovima, nastavnim grupama, specijalnostima, brojnom stanju, prostorija ma i dr.;

- unošenje podataka o terminima realizacije predmeta;

- unošenje podataka o terminima održa vanja is pita;

- izrada, ažuriranje i štampanje svih potrebnih izveštaja prema korisnicima (za smer, nastavnu grupu, nastavnika, po danima, terminima itd.);

- kreiranje polazne osnove rasporeda casova i pla na is pita za naredni semestar (zimski ili letnji) ili školsku godinu, na osnovu podataka iz prethodnog (bez termina za plan is pita);

- automatska provera is pravnosti unetih podataka (o preklapanju prostorija, predmeta, na stavnika i dr.). 
Informacioni sistem zamišljen je tako da radi u mrežnom okruženju i da podržava više razlicitih nivoa prava pristupa podacima.

Nakon definisanja prava pristupa pristupilo se izradi modela podataka. U ovoj fazi narocito je trebalo obratiti pažnju na univerzalnost modela i mogucnosti nje govog proširenja. Informacioni sistem za pla niranje rasporeda casova i izradu plana ispita automatizuje samo deo poslova nastavnog organa.

\section{Model podataka i predložena arhitektura sistema}

Za izradu modela podataka softverskih rešenja korišcen je CASE alat ERwin zbog svoje rasprostranje nosti i mogucnosti automatskog generisanja baze podataka iz projektovanog modela. Logic ki model podataka za softver raspored casova prikazan je na slici 1 .

Model podataka sacinjen je tako da omogucava maksimalnu efikasnost pri generisanju svih potrebnih izveštaja vezanih za raspored casova. Kljuc nu tabelu u ovom modelu (slika 1) predstavlja tabela StavkaRasporeda koja sadrži sve relevantne podatke bitne za jedan cas (predmet koji se sluša, obrazovni profil koji ga sluša, nastavnik koji predaje, termin i prostorija).

Logicki model podataka za softver plan is pita prikazan je na slici 2 .

Kljucnu tabelu u modelu podataka za softver plan is pita (slika 2) predstavlja tabela Ispit koja sadrži sve relevantne podatke bitne za pla niranje ispita u odredenom ispitnom roku (predmet koji se pola- že, nastavne grupe koje polažu, predmetni nastavnik, datumi polaganja ispita, itd.).

Svi ovi atributi se kao strani kljucevi prenose iz ostalih tabela, takozvanih šifarnika. Na taj nacin obezbedeno je da se ge nerisanje jednog termina za predavanje ili ispit vrši samo izborom željenih podataka iz liste ponudenih, cime je maksimalno smanjena mogucnost nastanka greške usled pogrešnog unosa.

Problem koji se ja vio pri izradi modela podataka kod oba softvera je su višestruke me dusobne zavisnosti koje postoje izme du nastavnih grupa razlicitih smerova, godina školovanja i spe cijalnosti. Nakon de taljne analize zahteva buducih korisnika informacionog sistema i tendencija razvoja školstva, usvojena je or ganizacija modela podataka prikazana na slikama 1 i 2 . Pojedini smerovi ne moraju imati na školovanju sve postojece specijalnosti, a neki, u zavisnosti od svoje or ganizacijsko-formacijske strukture, ne moraju imati ni citavu godinu školovanja (kla su studenata).

Tabele Katedra i OrgJed (slike 1 i 2) uve dene su da bi se omogucilo grupisanje nastavnika koji izvode nastavu u dve grupe: nastavnici sa katedri visokoškolske ustanove koja je nosilac realizacije nastave $i$ ispita i spoljni saradnici koji se angažuju preko drugih visokoškolskih ustanova (fakulteta Beogradskog univerziteta, Ministarstva odbrane ili iz jedinica Vojske Srbije).

$\mathrm{Na}$ taj nacin omoguceno je la ko i selektivno generisanje izveštaja o nastavnim oba vezama u predstojecem semestru i njihovo bla govremeno dostavlja nje svakoj pojedinacnoj organizacionoj je dinici ciji nastavnici realizuju nastavu i ispite. 


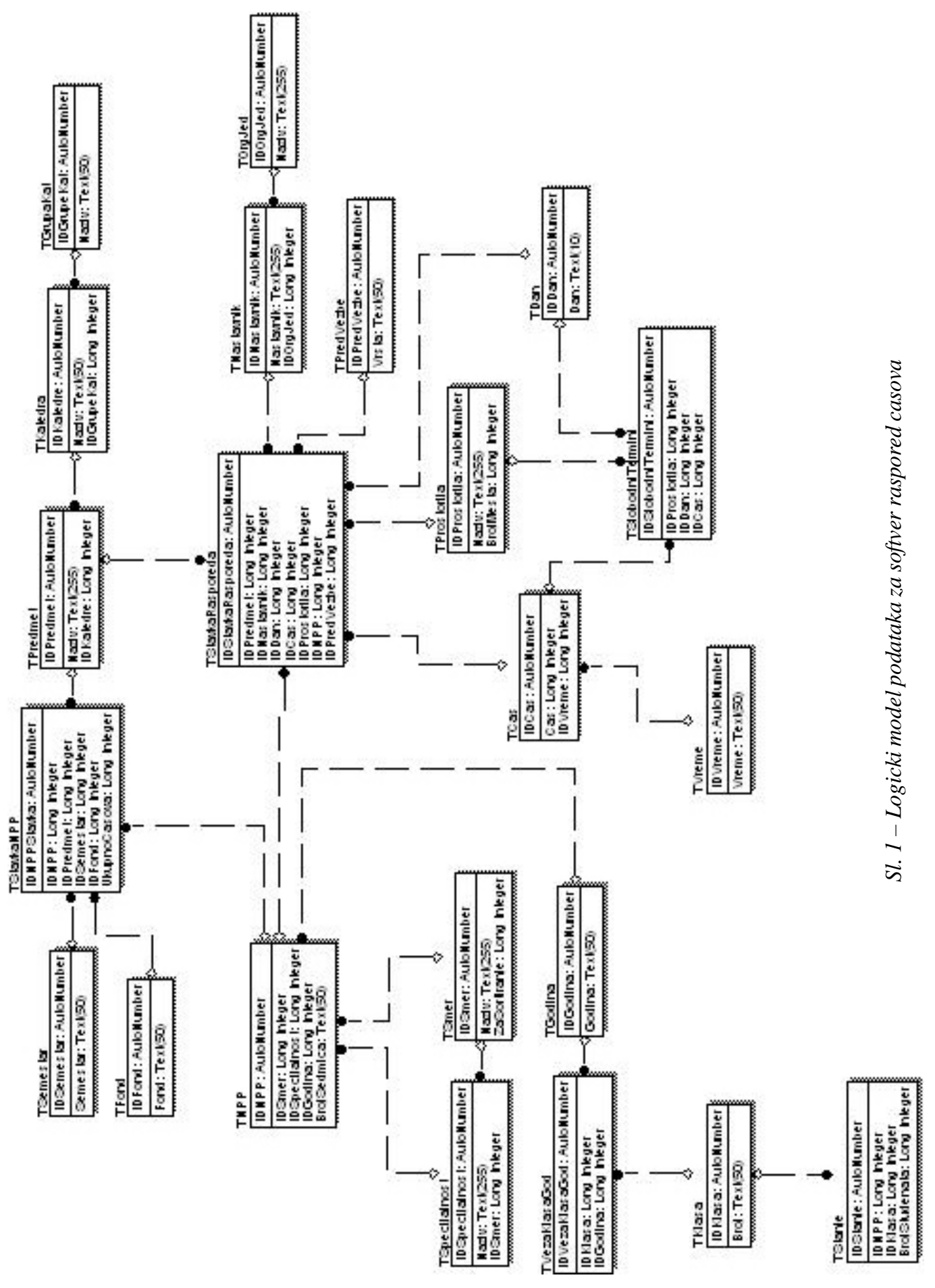

VOJNOTEHNIČKI GLASNIK 4/2006. 


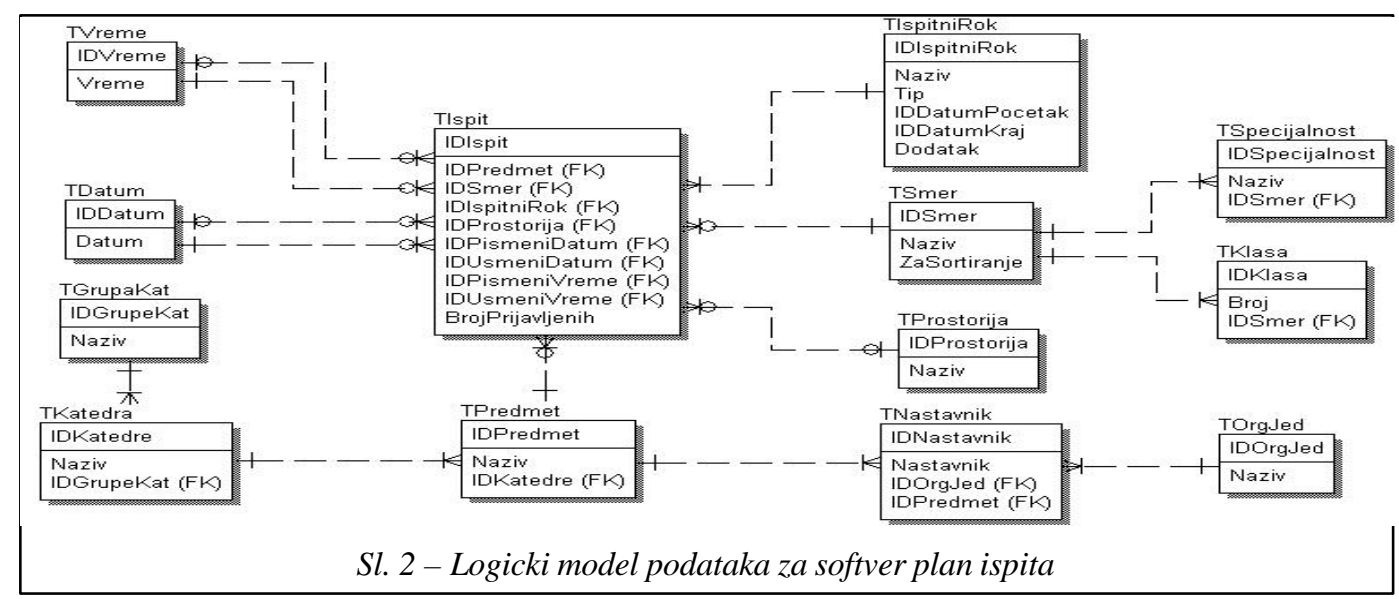

Za implementaciju informatickog rešenja oba softvera izabrana je troslojna arhitektura sistema, prikazana na slici 3.

Nakon izrade modela podataka pristupilo se generisanju baze podataka u kojoj ce se pohranjivati svi buduci podaci. Kao sistem za upravlja nje bazom podataka (server baze podataka) izabran je Mic rosoft SQL Server 2000. Razlozi za ovakav izbor bili su višestruki. SQL Server je alat koji je najrasprostranje niji u Vojsci Srbije, a izucava se i u okviru kursa na redovnim studija ma na smeru službe informatike. S obzirom na to da se jedne školske godine pla nira nastava za jednu grupu specijalnosti, dok se naredne ja vlja potreba pla niranja nastave za neke druge specijalnosti, odnosno da jedna školska godina ima šest redovnih i tri vanredna is pitna roka, kolicina podataka koja se ja vlja može da prevazide mogucnosti nekih skromnijih ala ta, kao što je Mic rosoft Access. Na kraju, ge nerisanje baze podataka je izuzetno efikasno realizovano, zbog mogucnosti automatskog kreiranja tabela u SQL Serveru iz modela poda taka sacinje nog u Erwinu.
Pošto je generisana baza podataka, za izradu korisnickog interfejsa izabran je Microsoft Access 2000 i pristupilo se izradi Data Projecta ${ }^{1}$, koji ce se koristiti za manipulaciju podacima, kao i za prikazivanje izveštaja. Odmah nakon završetka ove faze projekta poceo je unos test-podataka i popunja vanje šifarnika.

Imple mentacija logike sistema vecim delom je realizovana na samom ser-

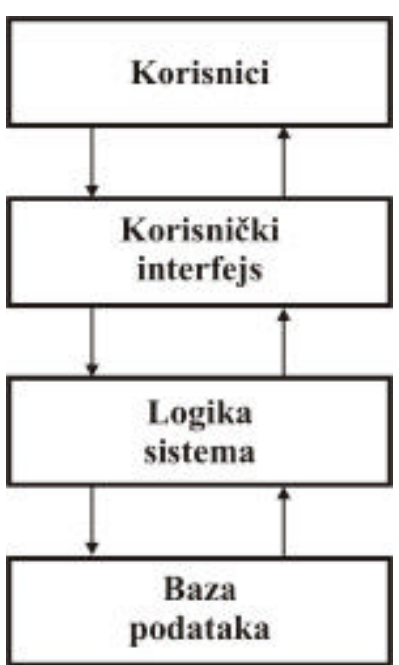

Sl. 3 - Troslojna arhitektura sistema

${ }^{1}$ Projekat napravljen u Microsoft Acces-u koji manipuliše vec postojecim podacima generisanim u nekom drugom SUBP. 


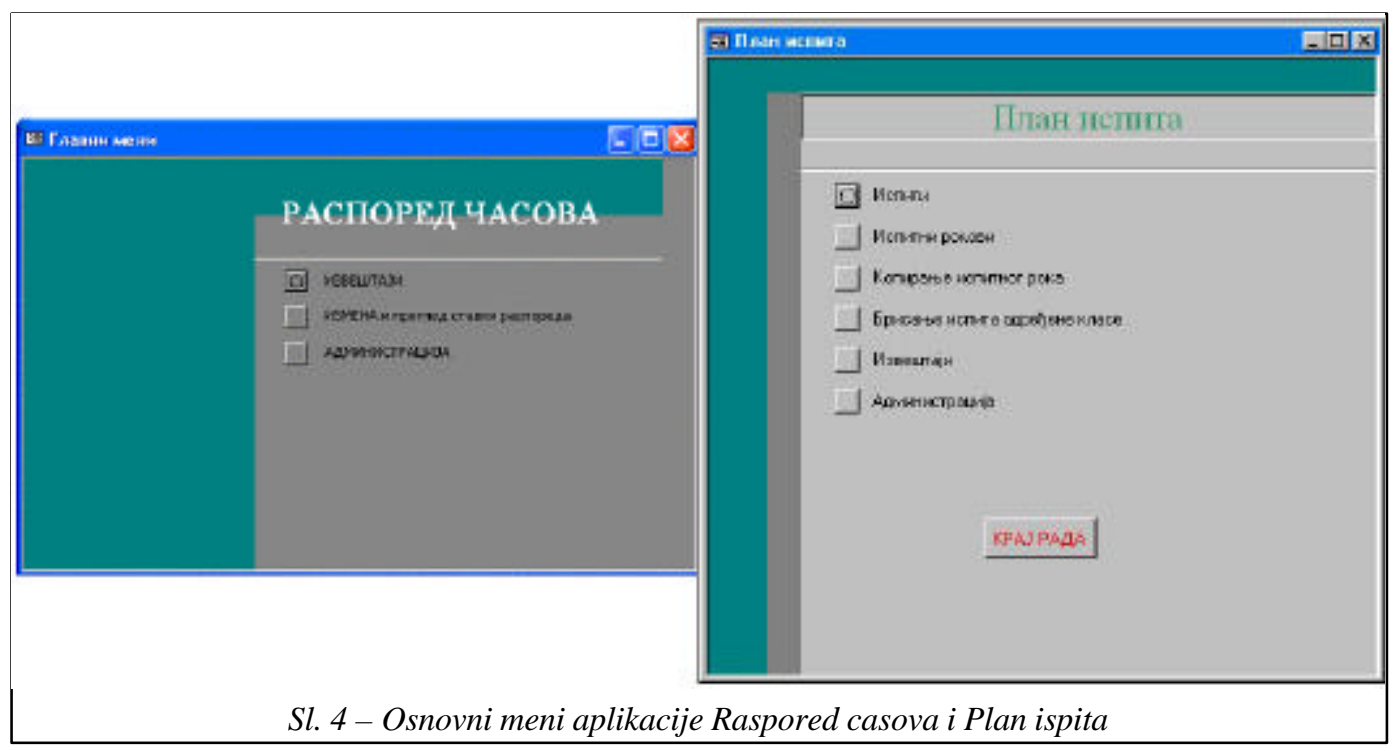

veru baze podataka, izradom uskla dištenih procedura $\mathrm{i}$ funkcija, a manji deo je imple mentiran $V B A^{2}$ kodom ugradenim $\mathrm{u}$ korisnicki interfejs. Korisnic ka aplikacija serveru baze podataka šalje zahtev za odredenim podacima, server vrši obradu podataka iz baze i korisniku šalje rezultate te obrade. Na ovaj nacin optimizovan je i ubrzan rad citavog siste ma kroz bitno smanjenje kolicine podataka koji se prenose kroz mrežu.

\section{Prikaz imple mentiranih rešenja}

Pri pokretanju aplikacija vrši se prija vljivanje korisnika za rad, pri cemu mu se dodeljuje jedan od cetiri definisana nivoa prava pristupa podacima. Nakon uspešnog prija vljivanja poja vljuje se osnovna forma aplikacije sa spiskom dostupnih akcija koje korisnik može da izvrši i podmenija kojima se može pristupiti u skla du sa definisanim pravima pristupa.

\footnotetext{
${ }^{2}$ Visual Basic for Applications - program ski jezik koji se koristi u alatima paketa Microsoft Offi ce.
}

Korisnic ki interfejs softverskih rešenja (slika 4) veoma je jednostavan i intuitivan, pa nje gova upotreba ne zahteva posebnu obuku korisnika.

Kljuc ne stavke menija ras poreda casova su izveštaji i izmena i pregled stavki rasporeda preko kojih se direktno pristupa rasporedu za odredeni obrazovni profil, odnosno for mi za ažuriranje, pregled i unošenje podataka rele vantnih za raspored odredenog profila.

Pristup formi za inicijalno pravljenje rasporeda smešten je u administraci$j i$, dok je pristup formi za izmenu i pregled stavljen na glavni meni. Takode, na glavni meni je stavljen pristup rasporedima, jer se tako na najbrži nacin kontrolišu izmene koje su oba vlje ne preko pomenute forme.

Inicijalna izrada jedne stavke rasporeda casova vrši se izborom opcije administracija (slika 4), a zatim unos stavki rasporeda. Tada se otvori forma UnosStavki (slika 6) preko koje se vrši unošenje svih relevantnih podataka izborom 
neke od ponudenih vrednosti iz padajucih lista (smer, kla sa, specijalnost, nastavnik, prostorija, predmet, cas, tip casa i dan). Mogucnost pogrešnog unosa podataka maksimalno je smanje na upotrebom padajucih lista. Podaci kojima se popunjava svaka od ovih lista direktno zavise od svih prethodno une tih podataka na formi. U listi Nastavnik nalazice se samo oni na stavnici koji realizuju izabrani predmet.

Izgled gotovog rasporeda za jednu nastavnu grupu prikazan je na slici 7 . U datom prikazu jednoznacno je dat termin (dan, cas), naziv predmeta, nastavnik, mesto izvodenja i tip casa. U slucaju da se neki predmet izvodi u neparnoj ili parnoj sedmici semestra, internim dogovorom takav predmet je oznacen jednom (ne parna sedmica) ili sa dve (parna sedmica) zve zdice.

Kljucne stavke menija Plana ispita su Ispiti i Ispitni rokovi preko kojih se direktno pristupa for mama za unošenje, pregle- danje i ažuriranje podataka rele vantnih za planiranje is pitnog roka. Unos jednog termina za pola ganje ispita vrši se izborom želje nog is pitnog roka i predmeta za koji se polaže is pit. Zatim se vrši unošenje svih ostalih bitnih podataka izborom ne ke od ponudenih vrednosti iz padajucih lista (smer, kla sa, spe cijalnost, na stavnik, prostorija i datumi pismenog i usmenog dela ispita) za svaku od nastavnih grupa koja treba da polaže izabrani is pit. Mogucnost pogrešnog unosa podataka maksimalno je smanje na upotrebom padajucih lista. Podaci kojima se popunjava svaka od ovih lista direktno zavise od svih prethodno unetih podataka na formi. Ako se izabere vazduhoplovnotehnic ki smer, za izbor klase bice ponudene samo one kla se koje taj smer trenutno ima na školovanju i samo specijalnosti koje postoje za izabrani smer i nje govu klasu. U listi Nastavnik nalazice se samo oni na stavnici koji realizuju izabrani predmet. Slika 5 prikazuje formu za unos podataka o is pitu.

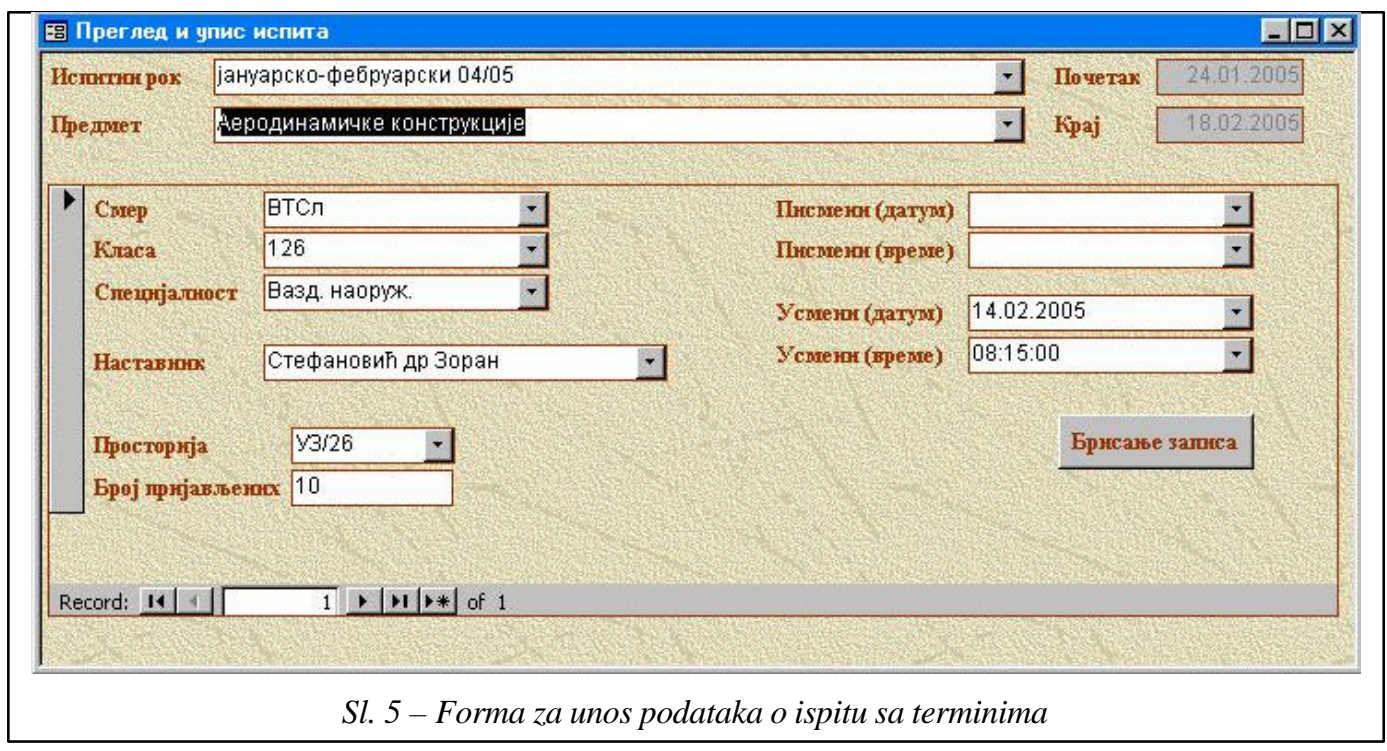


Stavka Kopiranje ispitnog roka u glavnom meniju Plana ispita (slika 4) realizovana je da bi se dala podloga za pripremu i izradu novog ispitnog roka. Izvršavanjem ove akcije vrši se kopiranje svih is pita iz nekog vec postojeceg ispitnog roka u novi ispitni rok, koji se planira, bez termina ispita. $\mathrm{Na}$ ovaj nacin, uz minimalne izmene, dobija se gotov obrazac Plana ispitnog roka.

Podmeni Izveštaji Plana ispita (slika 4) sadrži kontrole za generisanje i štampanje svih potrebnih izveštaja o is pitnom roku. Želje ni podaci dobijaju se jednostavnim iz- borom neke od ponudenih vrednosti iz padajucih lista. Omoguceno je generisanje i štampanje kompletnih izveštaja za željeni ispitni rok (smerove, specijalnosti i kla se) po nekom od kriterijuma (po predmetima, smerovima, klasama, datumima, itd.), kao i izrada parcijalnih izveštaja koji se dostavljaju odredenoj organizacionoj jedinici (katedrama, fakultetima - spoljnim saradnicima, licima po ugovoru o delu i dr.). Postoji i mogucnost spajanja više ispitnih rokova u jedan izveštaj. Za takvim izveštajem može se ukazati realna potreba zbog specificnosti

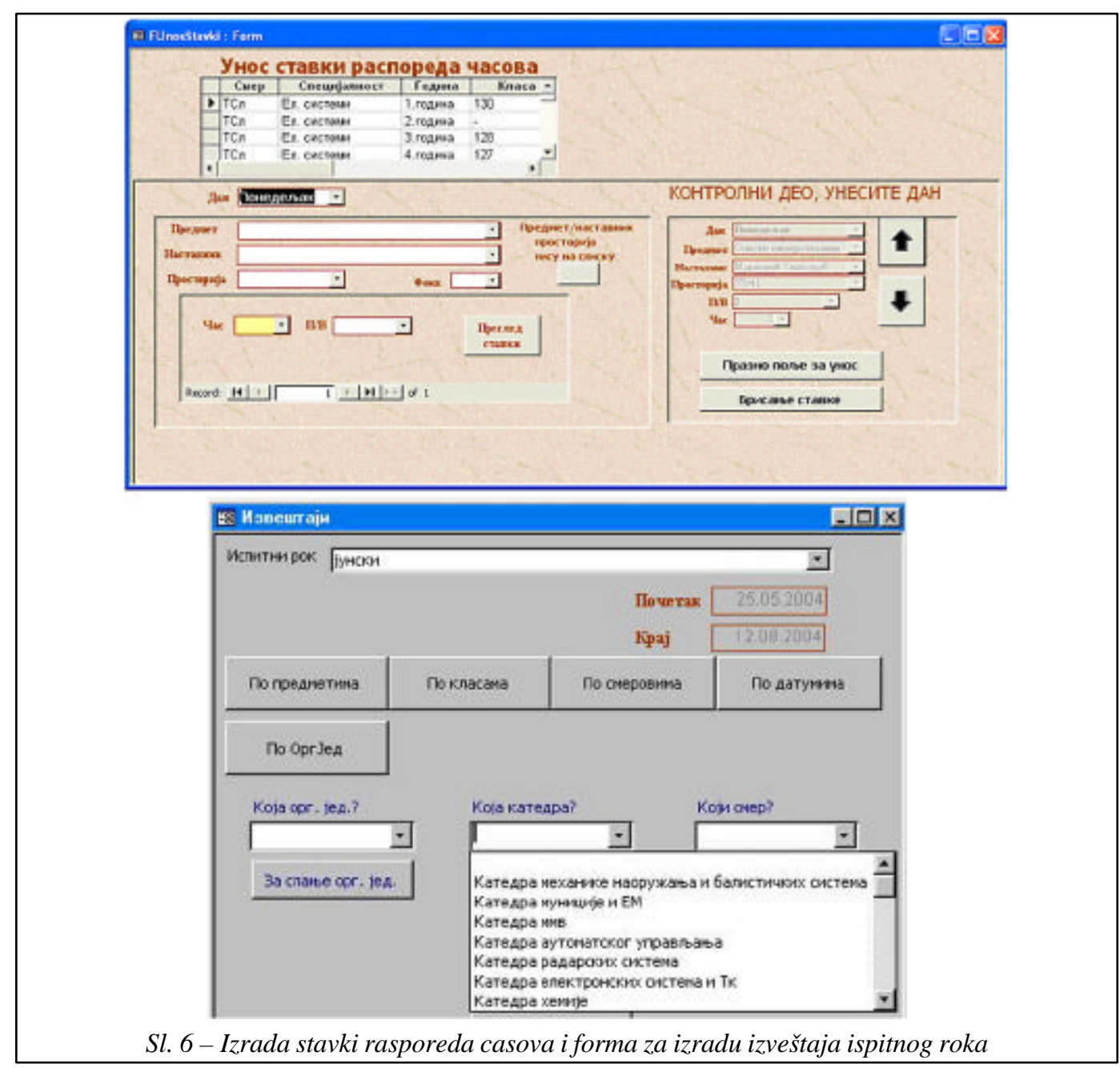


u gantogramu aktivnosti pojedinih godina školovanja i smerova (ispitni rokovi završne godine školovanja i ostalih godina). Forma za izbor kriterijuma na osnovu kojih se vrši generisanje iz veštaja prikazana je na sl. 6 .

Dnevna realizacija is pita u vojnim vi sokoškolskim ustanovama prati se putem službe dežurstva. Svaka nastavna grupa, u okviru redovnog dnevnog izveštavanja, dostavlja dežurnom or ganu podatke o ispitima realizovanim tog dana. Dežurna služba vrši evidenciju realizovanih is pita na vec pripremlje nom obrascu (izvod iz pla na polaganja za odredeni datum) i dostavlja izveštaj nastavnom organu. Izvršavanjem stavke Spisak ispita po datumu za DOF-a iz menija izveštaja automatski se dobija obrazac pregle da polaganja ispita za željeni datum. Ovaj obrazac sadrži spisak svih is pita koji treba da budu realizovani odredenog datuma, grupisanih po nastavnim grupama. Izgled obrasca prikazan je na slici 7 .

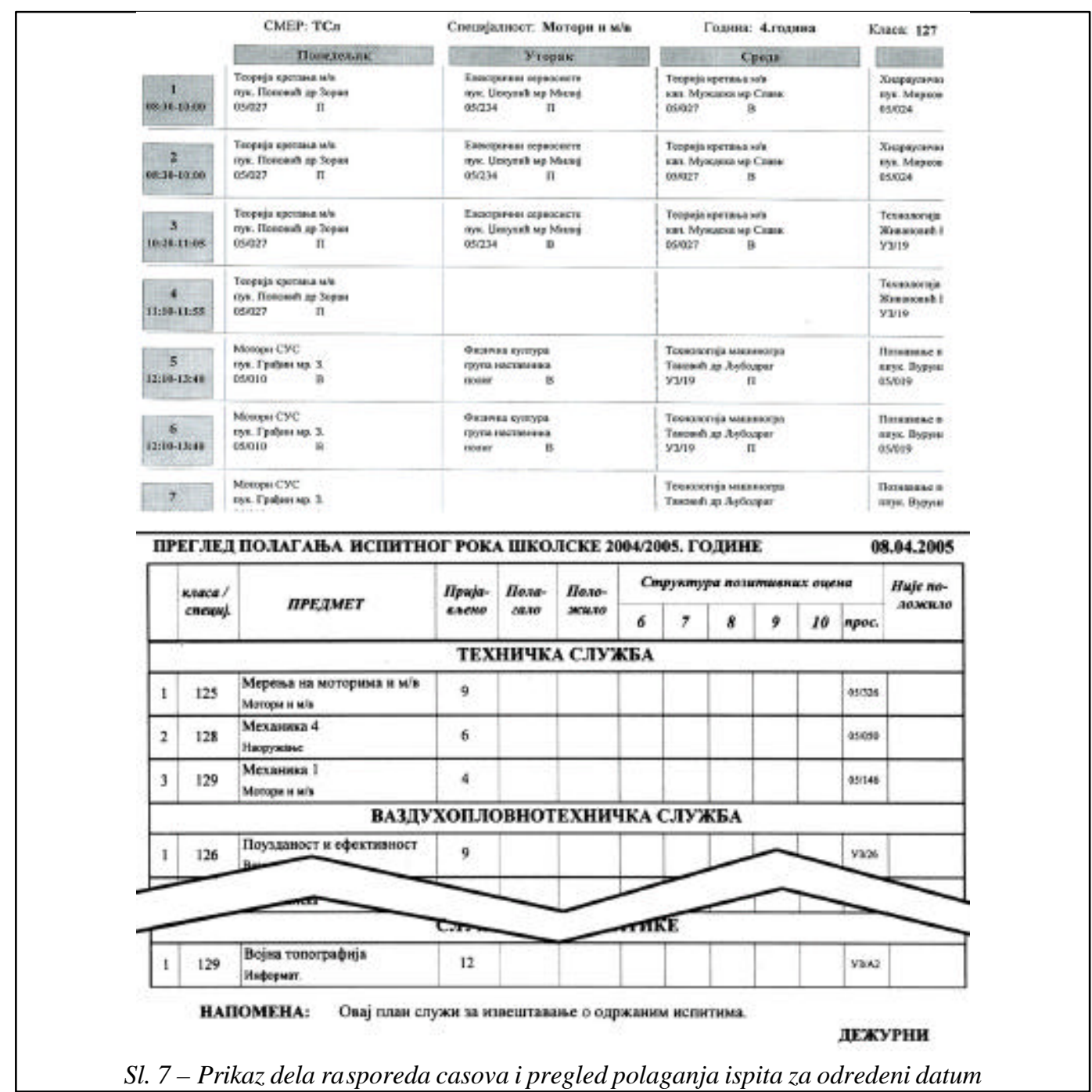


Aplikacija rasporeda casova na jednostavan nacin prikazuje greške koje se mogu ja viti pri pla niranju ras poreda. Jedna od najcešcih može da bude da se u istom terminu is planiraju predavanja ili vežbe dva razlicita predmeta (slika 8 ). U tom slucaju, kao što je to prikazano na slici, jednostavno treba obrisati je dan od predmeta (u ovom slucaju mehaniku 5, sreda 2. cas).

Vec je objašnje no koliko je sam proces pla niranja is pitnog roka složen $i$

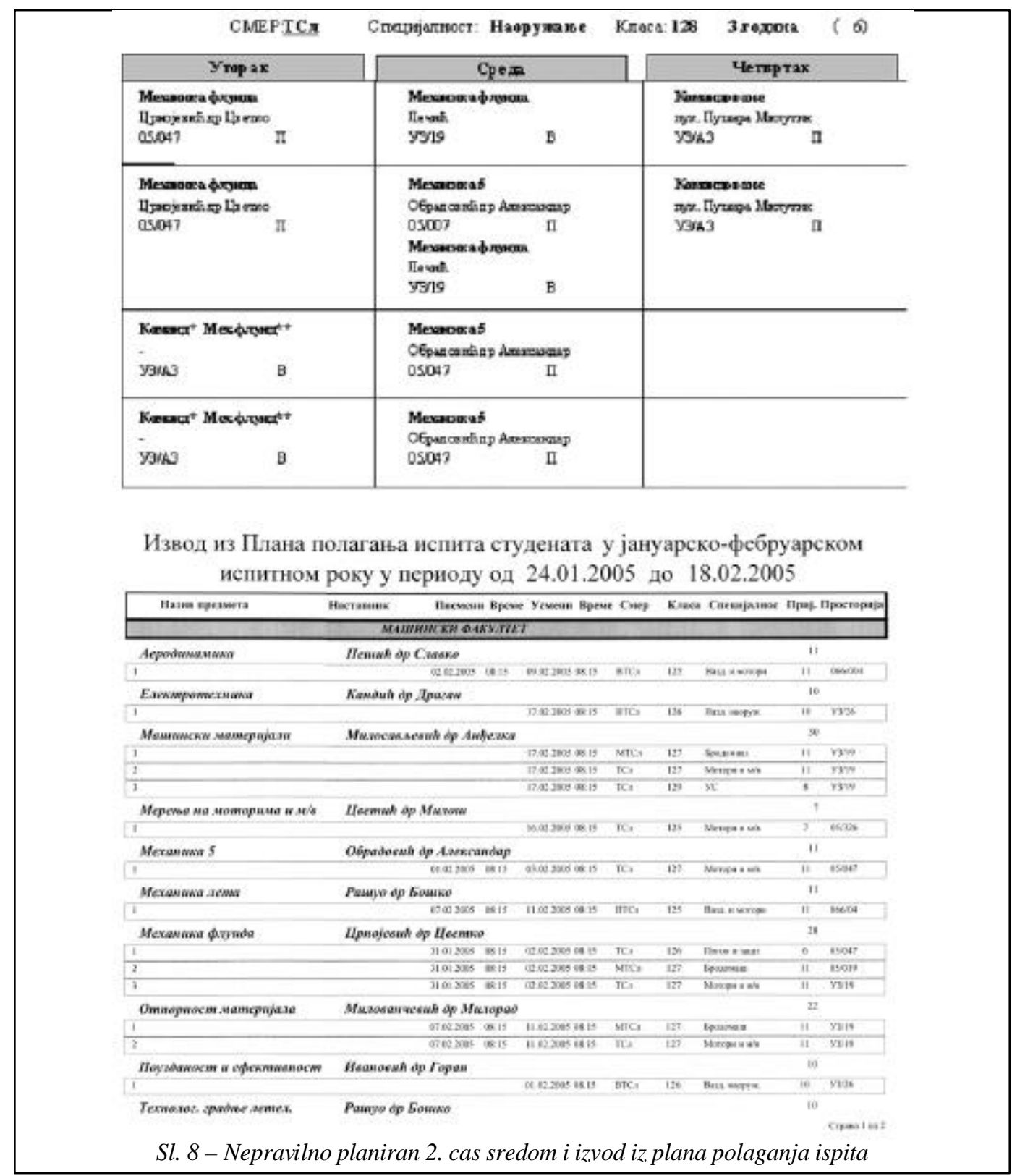


dinamican. I pored višestrukih koordinacija i provera termina za realizaciju ispita, što oba vlja referent u nastavnom organu, vrlo la ko mogu nastati greške u samom pla niranju. Posle dice tih grešaka su da odredena mastavna grupa može imati planiran pismeni i usmeni deo ispita istog dana ili da jedna nastavna grupa ima dva razlicita ispita $u$ jednom danu, pa cak i u isto vreme. Aplikacija mora da obezbedi otkrivanje takvih grešaka i omoguci njihovo ispravlja nje. Za rešenje tog proble ma postojale su dve mogucnosti. Prva je da aplikacija vec pri izradi pla na ispitnog roka one moguci unose termina za ispite koji bi narušavali konzistentnost podataka, a druga da se nakon izrade celokupnog pla na, putem provere svih podataka i generisanja izveštaja, pla neri upozore na kritic ne termine, koje zatim oni sami preplaniraju. Odluceno je da se implementira druga mogucnost zbog vece fleksibilnosti u radu.

Po završetku izrade pla na ispitnog roka izvodi iz pla na šalju se svim or ganizacionim je dinicama, ciji pripadnici ima$\mathrm{ju}$ is pitne obaveze u predstojecem is pitnom roku. Primer izvoda prikazan je na slici 8.

Da bi se izbegle greške pri izradi izvoda iz pla na ispita, za svakog nastavnika koji se nalazi u bazi podataka mora biti definisana or ganizaciona je dinica kojoj pripada. Aplikacija ima mogucnost provere navedenih poda taka i ge nerisanja izveštaja sa spiskom eventualnih nastavnika za koje nisu definisane organizacione jedinice kojima pripadaju.

Sve navedene provere realizovane su u meniju izveštaja kroz stavku Provere podataka.

\section{Zakljucak}

U radu su predstavlje na softverska rešenja za podršku pla niranju nasta ve u visokoš kolskim obrazovnim usta novama. Rešenje je realizovano radi automatizacije u izradi pla na, kreiranju izveštaja prema korisnicima (sme rovima, nastavnim grupama, studentima, nastavnicima, fakultetima - spoljnim saradnicima, itd.) i automatskoj proveri ispravnosti unetih podataka. Koncepcija rešenja omogucava rad u mrežnom okruženju i unos i cuvanje podataka rasporeda casova i pla na ispita za sve obrazovne profile na jednom mestu.

Za imple mentaciju rešenja odabrane su Mic rosoftove tehnologije kao najrasprostranjenije i opšte prihvacene $u$ Voj sci Srbije. Kao sistem za upravlja nje bazom podataka iskorišcen je Mic rosoft SQL Server 2000, a za izradu korisnickog interfejsa Mic rosoft Access 2000. Ovakvo opredelje nje omogucava upotrebu aplikacija u svim or ganizacionim celinama Vojne akademije i usta novama koje se ba ve visokoškolskim obrazovanjem, bez ili uz vrlo male izmene postojece hardverske i softverske infrastrukture. Bitan opredeljujuci faktor je ste i navika i iskustvo buducih korisnika u radu sa Mic rosof tovim tehnologijama.

Vreme potrebno za izradu rasporeda casova i pla na ispita bitno je skraceno, a kvalitet izradenih izveštaja poboljšan je automatskim otkrivanjem i lakim ispravlja njem uocenih grešaka u planiranju. Pracenje i realizacija nastave una predeni su jednostavnom izradom izveštaja koji se blagovremeno dostavljaju svim ucesnicima u procesu školovanja, kao i fakultetima Beogradskog univerziteta. 
Uz stalnu saradnju sa korisnicima proces unapredenja funkcionalnosti i korisnickog interfejsa realizuje se neprekidno.

Zahvaljujuci univerzalno projektovanom modelu podataka, imple mentirana rešenja se, uz minimalne izmene, mogu primeniti u bilo kojoj visokoškolskoj usta novi unutar i van Vojske Srbije.

\section{Literatura:}

[1] Gunderloy, M.: SQL Server 2000, Mikro knjiga, Beograd, 2001

[2] Grupa autora: Maj stor za Access 2002 VBA, Kompjuter biblioteka, Cacak, 2001.

[3] Tot, I.: Access 2000 - Skripta, Beograd, 2001

[4] Sceppa, D.: Programming ADO, Microsoft Press, Redmond, 2000.

[5] Nastavni planovi i programi Odseka logistike, Vojna akademija, Beograd, 1997. 